\title{
Changing Credit Conditions
}

\begin{abstract}
A
GREAT CHANGE has occurred in credit conditions in the past two or three months. Time and savings deposits in commercial banks and other financial intermediaries have risen significantly; the nation's money supply has stopped declining; most interest rates have declined sharply; and credit has apparently become more readily available. These developments may be most appropriately appraised by comparing recent experience with somewhat longer-run trends and by considering changes in specific factors underlying expansion of money and credit, such as Federal Reserve actions.
\end{abstract}

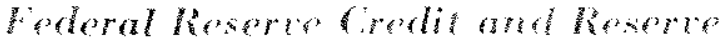 Expansion}

Federal Reserve credit, as measured by System holdings of securities plus member bank borrowings from the System, has grown very rapidly since October. This indicator of monetary action grew at an annual rate of 12 per cent from October to January after increasing at only a 4 per cent rate from April to October (adjusted for changes in requirements for reserves on time deposits). This credit increased 8 per cent in the 12 months ended in April 1966 and at an average 9 per cent rate from 1961 to 1965 .

The recent rapid rate of increase in Federal Reserve credit was large enough to provide a 5 per cent rate of growth in total reserves of member banks from October to January. Reserves for member banks are cash in vault and deposits in Reserve Banks, and, since banks must support their deposits with reserves, the volume of reserves is a restraint on the volume of bank deposits. From April to October total reserves had decreased at an annual rate of about 2 per cent following a 5 per cent increase in the year ended in April.

Most of the gains in reserves were used to support Government and time deposits. Reserves available to support private demand deposits (the major component of the money supply) have shown little change since October following a decrease at a 4 per cent annual rate from April to October and a 5 per cent increase in the preceding year.

\section{Montry stock}

The nation's money stock-private demand deposits plus currency held by the public-showed little net change from October to January. From April to October money declined at a 1.5 per cent rate. Money increased 6 per cent in the 12 months ended in April 1966 and at an average 3 per cent rate from 1961 to 1965.

\section{Money Stock}

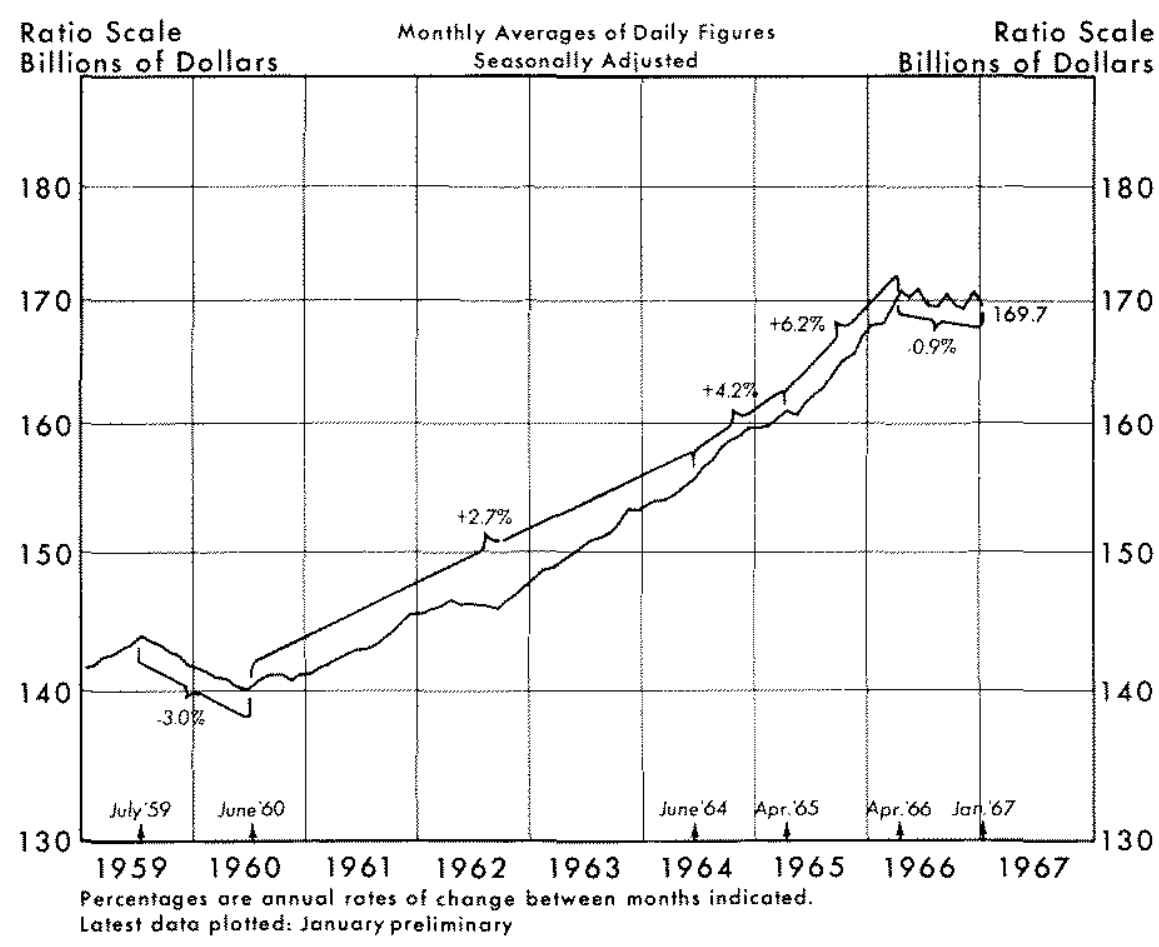


Interest Rates Monthly Averages of Daily Figures

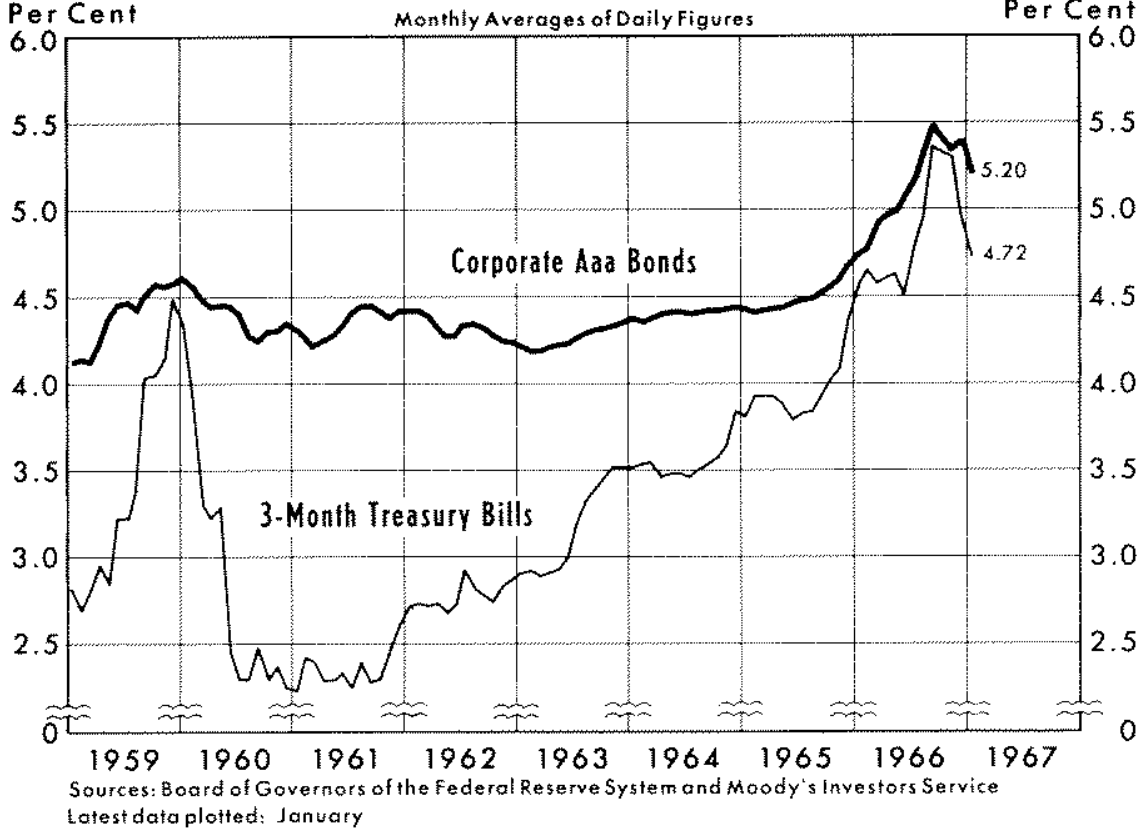

by large banks, for example, rose at a 25 per cent annual rate from late December to early February after remaining relatively stable from August to December and rising 20 per cent in the year ended in August.

\section{frierest Rales}

Most interest rates have moved lower in recent months after rising sharply in the last half of 1965 and the first three quarters of 1966. Yields declined moderately from September to November, perhaps in part as a technical reaction to the marked rise that occurred during the summer.

In December and January the decrease in interest rates accelerated. The lower rates probably reflected in part a lessening in the demands for credit. Sales and production have risen at slower rates in recent months, and demands for credit usually parallel these developments. Seasonally, there has generally been a smaller demand for eredit in January than in the fall when crops move to market and inventories are expanded for Christmas.

It is not apparent that the renewed intermediation role of the commercial banks since December and the consequent increase of bank credit provides an ex-

\section{Industrial Production}

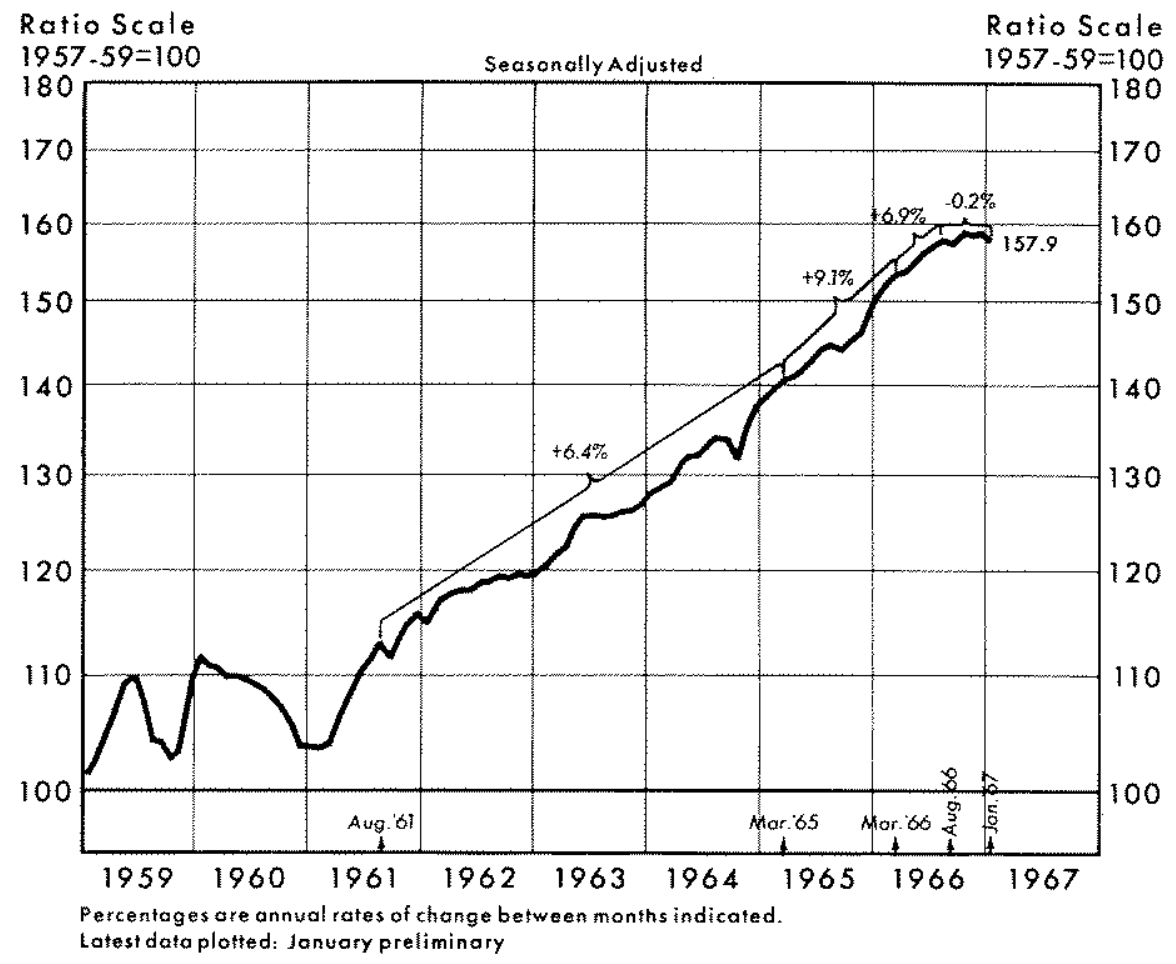


planation of the general downward movement of interest rates. Rather, the market interest rate decline relative to the rates banks are permitted to pay on time deposits explains the growth of bank credit and presumably an eclipse of some other avenues of financial intermediation.

Despite the decline since last September interest rates still remain at high levels relative to most past periods.

\section{SELECTED NNTEREST RATES}

Ayeroges of Daily Yields

\begin{tabular}{|c|c|c|c|c|}
\hline & 1950 & 1965 & $\begin{array}{c}\text { Seplember } \\
1966\end{array}$ & $\begin{array}{c}\text { February } 17 . \\
1967\end{array}$ \\
\hline 3-month Treasury bills & $1.22 \%$ & $3.95 \%$ & $5.36 \%$ & $4.62 \%$ \\
\hline long-term Government bonds & 2.32 & 4.21 & 4.79 & 4.49 \\
\hline $\begin{array}{l}\text { Highest-grade corporate } \\
\text { bonds }\end{array}$ & 2.62 & 4,49 & 5.49 & 5.01 \\
\hline $\begin{array}{l}\text { 4- to } 6 \text {-month commercial } \\
\text { paper }\end{array}$ & 1.45 & 4.38 & 5.89 & 5,38 \\
\hline
\end{tabular}

\section{Comsumer Credit Derelopments}

Consumer instalment debt has continued to increase in recent months, but much less rapidly than a year ago. From August to December this indebtedness rose at a 7 per cent annual rate compared with a 13 per cent rate of increase in the like period a year earlier. This slowing in the rate of growth of consumer debt has been rather steady for a year and a half. Around mid-1965 this debt was growing at about a 14 per cent annual rate. From the summer of 1965 to

\section{Consumer Instalment Credit}

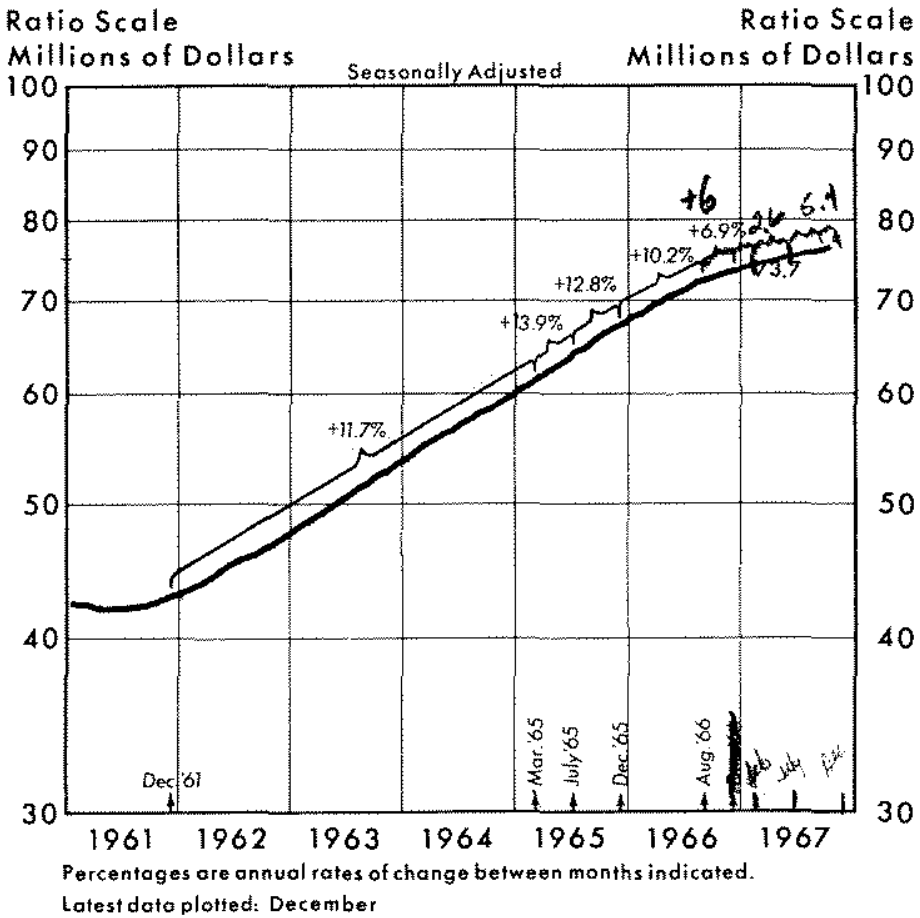

the end of the year the rate was about 13 per cent, while from then to late summer 1966 growth was at a 10 per cent rate.

The recent growth rate of 7 per cent in consumer instalment credit is low compared with the 8.5 per cent rate growth in personal income in the same period and with the 12 per cent annual growth in instalment credit from 1961 to 1965 . It is about the same as the rate of credit growth from 1955 to 1961 . Growth in the late 1950's was sharply down from the extremely rapid 17 per cent a year increase from 1949 to $\mathbf{1 9 5 5}$.

\section{CONSUMER INSTALMENT DEBT}

Annual Rates of Increase

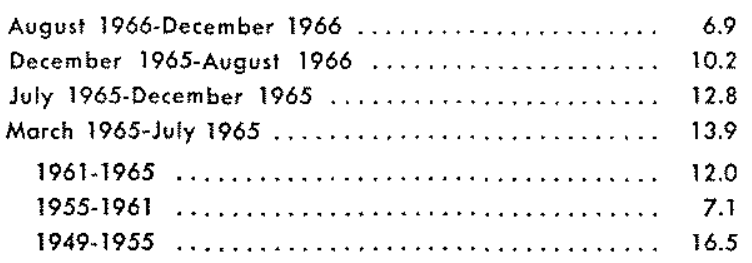

Credit for the purchase both of automobiles and of other consumer goods increased less rapidly in the last four months of 1966 than a year earlier. However, the decline in the rate of growth appeared considerably earlier for automobile paper than for other consumer goods credit.

Automobile credit outstanding rose from the spring of 1965 to the end of the year at about a 15 per cent annual rate. From then to March 1966 growth was at a 10 per cent pace. From March to December automobile credit expanded at a 7 per cent rate. This recent rate of expansion compares with a 14 per cent rate in the 1961-65 period, 4 or 5 per cent from 1955 to 1961 , and about a 20 per cent rate from 1949 to 1955.

\section{AUTOMOBILE INSTALMENT DEBT}

Annual Rates of Increase

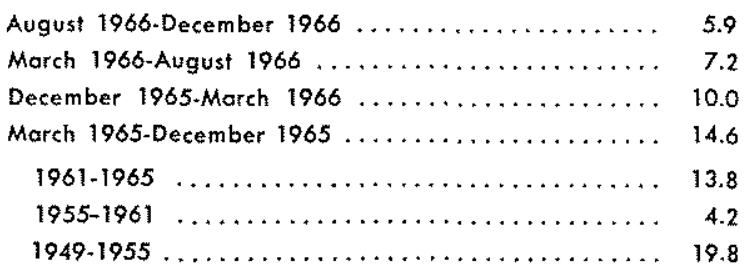

Credit for the purchase of consumer goods other than autos showed no decline in the rate of expansion until September. This credit grew at a rate of about 14 per cent a year from the spring of 1965 to Angust 1966; growth then lessened to an annual (Continued on page 24) 
rate of 12 per cent in September, 8 per cent in October, 7 per cent in November, and 9 per cent in December.

The growth of credit to purchase consumer goods other than automobiles at a 9 per cent annual rate from August to December compares with an increase at an 11 per cent rate from 1961 to 1965 , an 8 per cent rate from 1955 to 1961 , and a 13 per cent rate from 1949 to 1955.

\section{OTHER CONSUMER GOODS DEBT}

Annual Rates of Increase

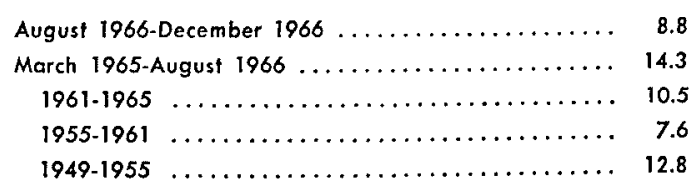

